\title{
Insulin-like growth factors in embryonic and fetal growth and skeletal development (Review)
}

\author{
GEORGIOS D. AGROGIANNIS $^{1}$, STAVROS SIFAKIS ${ }^{2}$, EFSTRATIOS S. PATSOURIS ${ }^{1}$ \\ and ANASTASIA E. KONSTANTINIDOU ${ }^{1}$ \\ ${ }^{1} 1$ st Department of Pathology, School of Medicine, University of Athens, Athens; \\ ${ }^{2}$ Department of Obstetrics and Gynecology, University Hospital of Heraklion, Crete, Greece
}

Received February 17, 2014; Accepted April 16, 2014

DOI: $10.3892 / \mathrm{mmr} .2014 .2258$

\begin{abstract}
The insulin-like growth factors (IGF)-I and -II have a predominant role in fetal growth and development. IGFs are involved in the proliferation, differentiation and apoptosis of fetal cells in vitro and the IGF serum concentration has been shown to be closely correlated with fetal growth and length. IGF transcripts and peptides have been detected in almost every fetal tissue from as early in development as pre-implantation to the final maturation stage. Furthermore, IGFs have been demonstrated to be involved in limb morphogenesis. However, although ablation of $I g f$ genes in mice resulted in growth retardation and delay in skeletal maturation, no impact on outgrowth and patterning of embryonic limbs was observed. Additionally, various molecular defects in the $I g f I$ and Igflr genes in humans have been associated with severe intrauterine growth retardation and impaired skeletal maturation, but not with truncated limbs or severe skeletal dysplasia. The conflicting data between in vitro and in vivo observations with regard to bone morphogenesis suggests that IGFs may not be the sole trophic factors involved in fetal skeletal growth and that redundant mechanisms may exist in chondro- and osteogenesis. Further investigation is required in order to elucidate the functions of IGFs in skeletal development.
\end{abstract}

\section{Contents}

1. Introduction

2. Role of IGFs in fetal growth

3. Expression levels of IGF genes and proteins in fetal serum and tissues

4. IGF-I in limb morphogenesis

Correspondence to: Dr Georgios D. Agrogiannis, 1st Department of Pathology, School of Medicine, University of Athens, 75 Mikras Asias Street, Athens GR-11527, Greece

E-mail: agrojohn@med.uoa.gr

Key words: insulin-like growth factors, insulin-like growth factor-I, insulin-like growth factor-II, fetal growth, skeletal development
5. IGF-I genetic disorders in humans

6. Conclusion

\section{Introduction}

The components of the insulin-like growth factor (IGF) system, include IGFs (IGF-I and IGF-II), type 1 and type 2 IGF receptors, a family of six secreted IGF-binding proteins (IGFBPs) and IGFBP proteases (1). The IGFs are single-chain mitogenic polypeptides, structurally similar to proinsulin, that function in an autocrine/paracrine manner and also as classical hormones. The two IGF receptors are structurally and functionally unrelated. IGF ligand signaling is mediated by IGF-1R, which is a transmembrane glycoprotein with tyrosine kinase activity (2). IGF-2R is a single-chain protein without kinase activity (3). IGF-1R binds IGF-I with up to 20 -fold higher affinity than for IGF-II, while IGF-2R strongly binds IGF-II, but barely recognizes IGF-I $(2,3)$. In biological fluids, IGFs are usually bound by members of the secreted IGFBP family, of which the exact role remains unknown. IGFBPs may serve as transport serum proteins, as IGF presentation molecules to the IGF receptors, as molecules prolonging IGF half-life or as a means for tissue-specific IGF localization. In addition, IGFBPs are considered to mediate IGF-independent actions via their own receptors (1). The $I g f 2$ and $I g f 2 r$ genes are imprinted, expressed in a monoallelic manner depending on parental legacy. In the murine embryo, only the paternal $I g f 2$ allele is expressed, while only the maternal $\operatorname{Ig} f 2 r$ allele is expressed (4). However, subsequent to birth, $\operatorname{Ig} f 2$ expression becomes biallelic in certain tissues, for example, in the liver (5). The present review focuses on the role of IGF-I in fetal growth and development, paying particular attention to skeletal development.

\section{Role of IGFs in fetal growth}

In initial IGF studies, the predominant roles of IGF-I and -II in fetal growth were elucidated by abundant but largely indirect evidence. IGFs were shown to act as proliferation and differentiation factors in cultured fetal cells (6-8) and preimplantation embryos (9), and were demonstrated to be secreted by cultured fetal cells and explants in vitro (10-11). 
Direct evidence of the importance of IGFs and IGF receptors in the regulation of embryonic and early postnatal growth was provided by a series of studies using gene knockout, analyzing the phenotypes manifested by mutations, alone or in combination (4). $\operatorname{Ig} f(-/ /-)$ nullizygotes and heterozygous mice carrying a paternally derived mutated $I g f 2$ gene were phenotypically indistinguishable (12). The mice were viable dwarfs with a birth weight $60 \%$ that of normal. Ablation of the IgfI gene (Igfl nullizygotes) resulted in a similar reduction of fetal growth (13) contradicting the prevailing hypothesis that IGF-II was the predominant mediator of fetal growth. Furthermore, the growth deficiency of the $I g f l$ mutants became evident at mouse embryonic day E13.5, when the size of the mutant embryos was $\sim 90 \%$ that of normal size, subsequent to which the $\operatorname{Igfl}(-/-)$ embryos continued to grow at a slower rate, thus the mice were $\sim 60 \%$ of normal size at the end of gestation (14). Surviving mutants continued to grow postnatally at a retarded rate, resulting in gaining only $30 \%$ of normal body weight as adults (14). This is in contrast to the normal birth weights observed in mice with GH-deficiency or GH-resistance $(15,16)$ and suggests that in prenatal mice, IGF-I is secreted independently of GH. Nevertheless, evidence indicates that GH acts as a local growth, differentiation and cell survival factor in the embryo, independent of IGF-I (17). Igflr nullizygotes exhibited an even greater reduction in birthweight (45\% of normal) and died immediately following birth (13). The proposed underlying mechanism for growth retardation of Igfl knock-out mice is that IGF-I and -II are not mitogenic per se. Deletion of $I g f l$ is suggested to lead to elongation of cell cycle time, resulting in fewer proliferation events during the same period and the generation of fewer cells than those required for the completion of embryonic development. In addition, evidence provided by Walenkamp et al (18) and Bhakta et al (19) show that the influence of IGF-1 on fetal growth is dose-related.

\section{Expression levels of IGF genes and proteins in fetal serum and tissues}

The two IGFs have been detected in the fetal plasma early in gestation in the majority of animal species investigated thus far (20-22), with plasma concentrations of IGF-II found to be several fold higher than those of IGF-I $(20,22)$. Notably, high IGF-II concentrations in fetal serum were demonstrated to decline within days following birth $(20,23)$, while serum concentrations of IGF-I appeared to be low in the fetus and rise in the immediate postnatal period, primarily as a result of the onset of GH-stimulated IGF-I production by the liver $(20,24)$.

In accordance with the findings regarding plasma concentrations of IGF-II, the majority of studies reported higher abundance of $I g f 2 \mathrm{mRNA}$ in fetal tissues compared with adult tissues (25). This raised the suggestion that IGF-II is the IGF that mediates growth and differentiation in developing fetal tissues. However, while IGF-II was revealed to be more abundant than IGF-I within the conceptus (serum and tissues), IGF-I was most closely associated with fetal growth in the majority of species. Thus, the plasma concentration of IGF-I, but not IGF-II, was found to correlate positively with fetal size and length, as well as birth and placental weight in humans (26-29). Alterations in the plasma or serum concentrations of IGF-I and IGFBP-1 and -3 have been identified in pregnancies complicated by preeclampsia and intrauterine growth restriction, where placental function is inadequate and fetal growth reduced (30-33). In such complicated pregnancies, the placental expression levels of IGF-I and IGFBP-1 are also decreased $(34,35)$.

Since serum concentrations may not reflect the production of peptides in specific tissues, several studies have attempted to detect the expression levels of $I g f$ genes and/or peptides in vivo. Using reverse transcription-polymerase chain reaction (RT-PCR), transcripts of $I g f$ and $I g f$ receptor genes were detected in the fetal tissues of various species between the earliest stage of pre-implantation and the final phase of tissue maturation (36-39), while sensitive hybridization methods have shown that $I g f$ gene expression was present in almost all human and rodent fetal tissues (40), including the liver, pancreas and osteochondrous tissue.

Previous studies regarding the distribution of IGFs in the bones of piglets and mice, revealed localization within the growth plate $(41,42) . \operatorname{Ig} f 1$ and $I g f 2$ mRNA was expressed throughout all zones, albeit Igfl less extensively. Immunohistochemical techniques also revealed the expression of IGFs within the resting zone, the hypertrophic zone and the proliferative zone of the growth plate (41) (Fig. 1). Additionally, with the use of RT-PCR, IGFs were also detected within the perichondrium and metaphyseal bone in rats (43).

\section{IGF-I in limb morphogenesis}

During mammalian embryogenesis, growth factors are important not only in cellular proliferation and differentiation but also in morphogenesis. The developing limb constitutes an attractive model of tissue morphogenesis. At the end of week 4 of gestation, the developing limb buds become visible as outpocketings from the ventrolateral body wall. Initially, the limb buds consist of a mesenchymal core derived from the lateral plate mesoderm that forms the bones and connective tissues of the limb, covered by a layer of ectoderm. The ectoderm at the distal border of the limb thickens and forms the apical ectodermal ridge (AER) (44). This ridge exerts an inductive influence on the adjacent mesenchyme, causing the mesenchyme to remain as a population of undifferentiated, rapidly proliferating cells, the progressing zone. As the limbs grow, cells farther from the influence of the AER begin to differentiate into cartilage and muscle. In this manner, development of limb proceeds proximodistally (44). Fingers and toes are formed when cell death in the AER separates the ridge into five parts. The zone of polarizing activity (ZPA) is an additional signaling region at the posterior margin of the limb mesenchyme that controls the antero-posterior patterning of the limb (45).

While the external shape is being established, the mesenchyme in the buds begins to condense and differentiate into chondrocytes. By week 6 of development, the first hyaline cartilage models, foreshadowing the bones of the extremities, are formed by these chondrocytes. Ossification of the bones of the extremities, endochondral ossification, begins by the end of the embryonic period. Primary ossification centers are present in all long bones of the limb by week 12 of development (44).

Several studies have demonstrated the predominant role of the IGFs in limb development. IGF-I has been demonstrated 


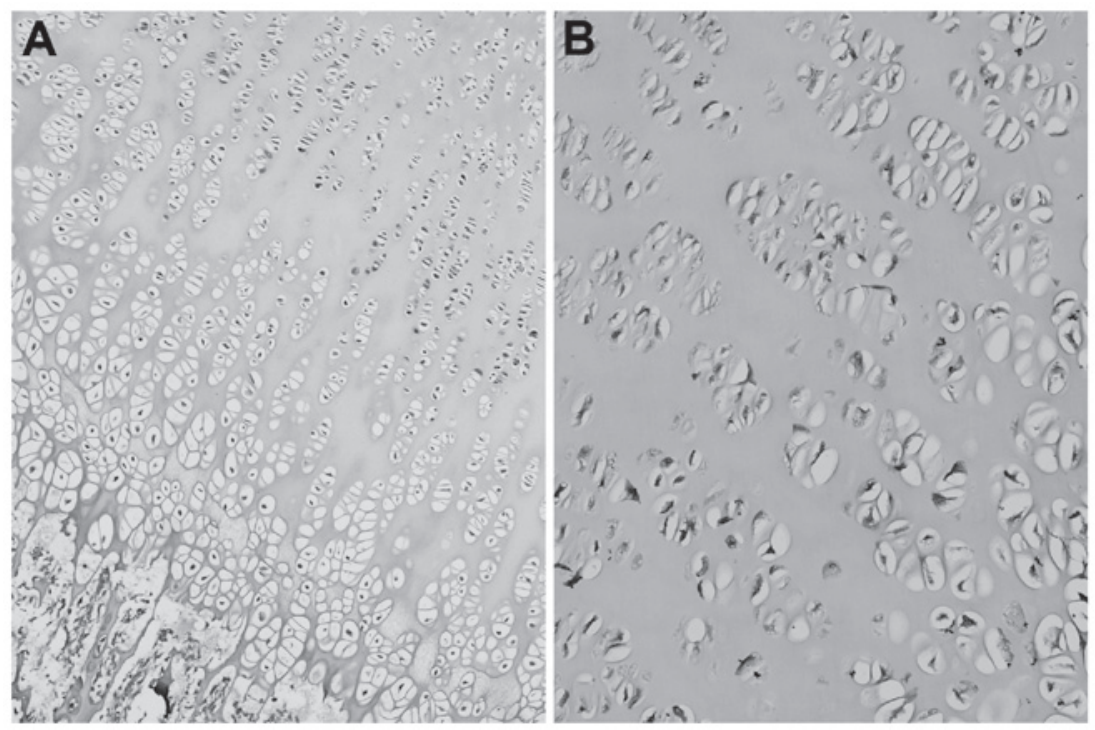

Figure 1. Human femur of a 22-week-gestation fetus: Insulin-like growth factor (IGF)1 cytoplasmic expression is localized in the chondrocytes of all layers in the growth plate. IGF1 immunohistochemical stain. (A) Magnification, x40. (B) Magnification, x200.

to stimulate proliferation of dissociated limb mesenchymal cells (46), isolated human fetal chondocytes (6), and explanted limb buds of rat and chicken embryos in vitro $(47,48)$. Other studies, using in situ hybridization and immunohistochemistry, have demonstrated that IGF-I and its receptor (IGF-1R) are expressed in vivo by the sub ridge mesodermal cells of the developing rat and chicken limb buds (49-52), while in mouse embryos IGF-I has also been detected in the progress zone (53), suggesting that IGF-I may be involved in promoting the proliferation and outgrowth of the limb mesoderm in response to the AER or ZPA regions. Furthermore, several studies have revealed $I g f l$ transcripts in the condensing central core of mouse and chicken limbs $(52,53)$, which implicates IGF-I in the regulation of chondrogenic differentiation. However, other studies did not detect $I g f I$ transcripts, and reported only $I g f 2$ and $I g f l r$ transcripts in the undifferentiated mesenchymal condensations and differentiated chondrocyte precursors in murine fetus chondrogenesis (54), verifying the results of in vitro experiments in limb organ cultures $(47,48,52)$. IgfI transcripts have been reported to be present in the osteoblast, osteo- and chondoclasts and nascent matrix of the long bones of developing chicken and mouse limbs, a location consistent with a potential role for IGF-I in endochondral bone formation (49). Notably, during the outgrowth and patterning of the limbs, IGF-I has been identified in mesoderm regions that undergo programmed cell death, including the interdigital zone in mouse and chicken embryos $(52,53,55)$. Therefore, IGF-1 is implicated in all activities (proliferation, differentiation and apoptosis) essential for proper limb morphogenesis.

Notably, no knock-outs of any IGF-axis member to date have been reported to result in defects in limb initiation, outgrowth or patterning. Thus, although $\operatorname{Ig} f l(-/ /)$ and $\operatorname{Ig} f 2(-/-)$ mutants exhibited growth impairment, only marginal ossification retardation occurred, and this did not exceed one embryonic day $(12,13)$. However, postnatal comparisons of wild-type and surviving $\operatorname{Ig} f(-/ /)$ mutants revealed the rate of long bone ossification to be greatly reduced in the mutants (14). Ablation of the Igflr gene resulted in a greater delay in the appearance of the ossification centers in facial and cranial bones (lag of $\sim 2$ embryonic days), and ossification of the interparietal bone exhibited an even longer delay ( $\sim 4$ days) (13). In support of these findings, the intravascular infusion of recombinant IGF-I in late gestation of fetal sheep resulted in no change in the lengths of the fetus and long bones. However, a rise in skeletal maturation was observed, as assessed by the acceleration of the appearance of epiphysial centers and the increase in cross-sectional areas of the bones (56). Furthermore, overexpression of IGF-I in mice resulted in disproportionate overgrowth of certain organs but no increase in the length of long bones (57). These observations indicate the existence of redundant mechanisms for the developmental processes of limb morphogenesis, including chondro- and osteogenesis, and/or compensatory actions of IGF-axis members. In this regard, Dealy and Kosher (58) observed that insulin mimics the effects of IGF-I in promoting AER induction and limb outgrowth in vitro, and Messiano et al (59) demonstrated that hypophysectomized lamb fetuses with normal plasma concentrations of IGF-I and IGF-II exhibited delayed osseous maturation, which was restored by thyroxine administration. These observations suggest that IGFs are not the sole trophic factors involved in fetal skeletal development. More recent studies, using novel methods to visualize and quantify differences in the structure and mineral density of fetal bones in I $f f(-/-)$ knock-out mice compared with bones in wild-type mice, report hypomineralization and differences in bone microstructure, possibly representing impaired remodeling activity in the absence of IGF-I $(60,61)$.

\section{IGF-I genetic disorders in humans}

In the last few years, reports of patients with genetic defects in various components of the IGF-axis have broadened knowledge regarding the role of IGFs in intra-uterine growth and development. The first human case concerning a patient with a homozygous partial deletion (exons 4 and 5) of the Igfl gene was described by Woods et al (62). This mutation was 
manifested by severe intrauterine growth retardation [birth weight -3.9 standard deviations (SD), birth length -5.4 SD and microcephalia] and dysmorphic features (micrognathia and bilateral clinodactyly), in addition to postnatal growth failure, including delayed bone age and severe osteopenia. Although the growth impairment of the Igfl null patient was relatively more severe than that of the Igfl knock-out mice (13), the overall phenotypic features were similar.

Since then, a variety of molecular defects in the Igfl gene have been reported, including homozygosity for a missense mutation (18), another missense mutation with a milder phenotype (63) and a nucleotide substitution (polymorphism) (64), which was later found to also occur in healthy controls (65). In 2010, van Duyvenvoorde et al (66), described a case of heterozygosity for a frameshift mutation characterized by short stature and microcephaly. Later, using molecular methods, the same group concluded that the short stature of the patients cannot be attributed exclusively to the $I g f I$ gene defect but to the combination of the $I g f l$ gene with other factors, including placental IGF-I insufficiency and other genetic factors (67). In any case, severe pre- and postnatal growth impairment, microcephaly, dysmorphic features, retarded skeletal maturation, deaf-mutism and mental retardation, though variable in density, appear to be common characteristics of patients with Igfl gene molecular defects.

In humans, the potential lethal effect from total loss of IGF-1R may explain why only heterozygous mutations in the Igflr gene have been reported to date. Thus, several cases of either heterozygosity for Igflr gene mutations (68-75) or Igflr gene haploinsufficiency (loss of the distal long arm of chromosome 15q26) have been reported (76-79). All patients exhibit a similar phenotype to patients with mutations in the $I g f l$ gene. However, compared with patients exhibiting heterozygosity for Igfrl mutations (Igfrl haploinsufficiency), patients with loss of the Igflr gene tend to have more prominent phenotypic abnormalities, with greater dysmorphic features, an increased delay in motor development and impaired psychosocial skills. The extent to which these features reflect the loss of contiguous genes on chromosome 15 is uncertain. The heterogeneity in the clinical phenotypes of patients with molecular defects in the $I g f l$ or $I g f l r$ genes may suggest variability in the degree of functional loss of the IGF-I/IGF-1R interaction and/or the involvement of other genetic or environmental factors.

\section{Conclusion}

The two IGFs and the main IGF receptor IGF-1R are indisputably important in embryonic and fetal growth and development, as indicated by in vitro findings, in vivo experiments with knock-out mice and case reports of patients with molecular defects in the IGF-axis members. Although IGF-II is more abundantly expressed in the serum and tissues of the conceptus than IGF-I, IGF-I appears to be more closely associated with fetal growth in the majority of species. IGF-I is generally considered to affect fetal growth in a dose-related manner, independently of GH. However, controversy remains surrounding the data from in vitro and in vivo observations, and the exact role of IGFs, as pertains to the prenatal development of the skeleton, remains uncertain. Further investigation is required in fetuses with impaired skeletal development, in the context of fetal growth restriction or skeletal dysplasia, in order to elucidate the role of the IGFs in fetal growth and skeletal development.

\section{References}

1. Jones JI and Clemmons DR: Insulin-like growth factors and their binding proteins: biological actions. Endocr Rev 16: 3-34, 1995.

2. LeRoith D, Werner H, Beitner-Johnson and Roberts CT Jr: Molecular and cellular aspects of the insulin-like growth factor I receptor. Endocr Rev 16: 143-163, 1995.

3. Kornfeld S: Structure and function of the mannose-6phosphate/insulin-like growth factor II receptors. Annu Rev Biochem 61: 307-330, 1992.

4. Efstratiadis A: Genetics of mouse growth. Int J Dev Biol 42: 955-976, 1998.

5. Davies SM: Developmental regulation of genomic imprinting of the Igf2 gene in human liver. Cancer Res 54: 2560-2562, 1994.

6. Vetter U,Zapf J, Heit W, et al: Human fetal and adult chondrocytes. Effect of insulin-like growth factors I and II, insulin, and growth hormone on clonal growth. J Clin Invest 77: 1903-1908, 1986.

7. Bhaumick B and Bala RM: Differential effects of insulin-like growth factors I and II on growth, differentiation and glucoregulation in differentiating chondrocyte cells in culture. Acta Endocrinol (Copenh) 125: 201-211, 1991.

8. Lorenzo M, Valverde AM, Ternel T and Benito M: IGF-I is a mitogen involved in differentiation-related gene expression in fetal rat brown adipocytes. J Cell Biol 123: 1567-1575, 1993.

9. Harvey MB and Kaye PL: Insulin-like grow th factor-1 stimulates growth of mouse preimplantation embryos in vitro. Mol Reprod Dev 31: 195-199, 1992.

10. Canalis E, McCarthy T and Centrella M: Isolation and characterization of insulin-like growth factor I (somatomedin-C) from cultures of fetal rat calvariae. Endocrinology 122: 22-27, 1988.

11. D'Ercole AJ, Applewhite GT and Underwood LE: Evidence that somatomedin is synthesized by multiple tissues in the fetus. Dev Biol 75: 315-328, 1980.

12. DeChiara TM, Efstratiadis A and Robertson EJ: A growth-deficiency phenotype in heterozygous mice carrying an insulin-like growth factor II gene disrupted by targeting. Nature 345: 78-80, 1990.

13. Liu J-P, Baker J, Perkins AS, Roberson EJ and Efstratiadis A: Mice carrying null mutations of the genes encoding insulin-like growth factor I (Igf-1) and type 1 IGF receptor (Igf1r). Cell 75: 59-72, 1993.

14. Baker J, Liu J-P, Robertson EJ and Efstratiadis A: Role of insulin-like growth factors in embryonic and postnatal growth. Cell 75: 73-82, 1993.

15. Wajnrajch MP, Gertner JM, Harbison MD, Chua SC Jr and Leibel RL: Nonsense mutation in the human growth hormone-releasing hormone receptor causes growth failure analogous to the little (lit) mouse. Nat Genet 12: 88-90, 1996.

16. Savage MO, Blum WF, Ranke MB, et al: Clinical features and endocrine status in patients with growth hormone insensitivity (Laron syndrome). J Clin Endocrinol Metab 77: 1465-1471, 1993.

17. Sanders EJ and Harvey S: Growth hormone as an early embryonic growth and differentiation factor. Anat Embryol (Berl) 209: 1-9, 2004.

18. Walenkamp MJ, Karperien M, Pereira AM, et al: Homozygous and heterozygous expression of a novel insulin-like growth factor-I mutation. J Clin Endocrinol Metab 90: 2855-2864, 2005.

19. Bhakta KY, Marlin SJ, Shen JJ and Fernandes CJ: Terminal deletion of chromosome 15q26.1: case report and brief literature review. J Perinatol 25: 429-432, 2005.

20. Gluckman PD and Butler JH: Parturition-related changes in insulin-like growth factors-I and -II in the perinatal lamb. J Endocrinol 99: 223-232, 1983.

21. Holland MD, Hossner KL, Williams SE, Wallace CR, Niswender GD and Odde KG: Serum concentrations of insulin-like growth factors and placental lactogen during gestation in cattle. Domest Anim Endocrinol 14: 231-239, 1997.

22. Lee CY, Chung CS and Simmen FA: Ontogeny of the porcine insulin-like growth factor system. Mol Cell Endocrinol 93: 71-80, 1993.

23. Moses AC, Nissley SP, Short PA, et al: Increased levels of multiplication-stimulating activity, an insulin-like growth factor, in fetal rat serum. Proc Natl Acad Sci USA 77: 3649-3653, 1980. 
24. Daughaday WH, Parker KA, Borowsky S, Trivedi B and Kapadia M: Measurement of somatomedin-related peptides in fetal, neonatal, and maternal rat serum by insulin-like growth factor (IGF) I radioimmunoassay, IGF-II radioreceptor assay (RRA), and multiplication-stimulating activity RRA after acid-ethanol extraction. Endocrinology 110: 575-581, 1982.

25. Lund PK, Moats-Staats BM, Hynes MA, et al: Somatomedin-C/insulin-like growth factor-I and insulin-like growth factor-II mRNAs in rat fetal and adult tissues. J Bio Chem 261: 14539-14544, 1986.

26. Gluckman PD, Johnson-Barrett JJ, Butler JH, Edgar BW and Gunn TR: Studies of insulin-like growth factor-I and -II by specific radioligand assays in umbilical cord blood. Clin Endocrinol (Oxf) 19: 405-413, 1983

27. Lassarre C, Hardouin S, Daffos F, Forestier F, Frankenne F and Binoux M: Serum insulin-like growth factors and insulin-like growth factor binding proteins in the human fetus. Relationships with growth in normal subjects and in subjects with intrauterine growth retardation. Pediatr Res 29: 219-225, 1991

28. Verhaeghe J, Van Bree R, Van Herck E, Laureys J, Bouillon R and van Assche FA: C-peptide, the insulin-like growth factors-I and -II, and IGF-binding protein I in umbilical cord serum: correlations with birthweight. Am J Obstet Gynecol 169: 89-97, 1993.

29. Giudice LC, de Zegher F, Gargosky SE, et al: Insulin-like growth factors and their binding proteins in the term and preterm human fetus and neonate with normal and extremes of intrauterine growth. J Clin Endocrinol Metab 80: 1548-1555, 1995.

30. Sifakis S, Akolekar R, Kappou D, Mantas N and Nicolaides KH: Maternal serum insulin like growth factor-I (IGF-I) at 11-13 weeks in preeclampsia. Prenat Diagn 30: 1026-1031, 2010.

31. Sifakis S, Akolekar R, Kappou D, Mantas N and Nicolaides KH: Maternal serum insulin-like growth factor binding protein-1 (IGFBP-1) at 11-13 weeks in preeclampsia. Prenat Diagn 31: 196-201, 2011

32. Sifakis S, Akolekar R, Kappou D, Mantas N and Nicolaides KH: Maternal serum insulin-like growth factor binding protein-3 (IGFBP-3) at 11-13 weeks in preeclampsia. J Hum Hypertens 26: 253-258, 2012

33. Sifakis S, Akolekar R, Kappou D, Mantas N and Nicolaides KH Maternal serum insulin like growth factor (IGF-I) and binding proteins IGFBP-1 and IGFBP-3 at 11-13 weeks' gestation in pregnancies delivering small for gestational age neonates. Eur J Obstet Gynecol Reprod Biol 161: 30-33, 2012

34. Koutsaki M, Sifakis S, Zaravinos A, Koutroulakis D, Koukoura O and Spandidos DA: Decreased placental expression of hPGH, IGF-I and IGFBP-1 in pregnancies complicated by fetal growth restriction. Growth Horm IGF Res 21: 31-36, 2011

35. Koukoura O, Sifakis S, Zaravinos A, et al: Aberrant methylation of IGF2 is associated with loss of imprinting in placentas from pregnancies complicated with fetal growth restriction. Int J Mol Med 28: 481-487, 2011

36. Watson AJ, Hogan A, Hahnel A, Wiemer KE and Schultz GA Expression of growth factor ligand and receptor genes in the preimplantation bovine embryo. Mol Reprod Dev 31: 87-95, 1992

37. Watson AJ, Watson PH, Arcellana-Panlilio M, et al: A growth factor phenotype map for ovine preimplantation development. Biol Reprod 50: 725-733, 1994

38. Zhang X, Kidder GM, Watson AJ, Schultz GA and Armstrong DT: Possible roles of insulin and insulin-like growth factors in rat preimplantation development: investigation of gene expression by reverse transcription-polymerase chain reaction. J Reprod Fertil 100: 375-380, 1994.

39. Lighten AD, Hardy K, Winston RM and Moore GE: Expression of mRNA for the insulin-like growth factors and their receptors in human preimplantation embryos. Mol Reprod Dev 47: 134-139, 1997.

40. Rotwein P, Pollock KM, Watson M and Milbrandt JD: Insulin-like growth factor gene expression during rat embryonic development. Endocrinology 121: 2141-2144, 1987.

41. Schlegel W, Halbauer D, Raimann A, et al: IGF expression patterns and regulation in growth plate chondrocytes. Mol Cell Endocrinol 327: 65-71, 2010.

42. Wang Y, Cheng Z, Elalieh HZ, et al: IGF1R signaling in chondrocytes modulates growth plate development by interacting with the PTHrP/Ihhpathway. J Bone Miner Res 26: 1437-46, 2011.

43. Parker EA, Hegde A, Buckley M, Barnes KM, Baron J and Nilsson O: Spatial and temporal regulation of GH-IGF-related gene expression in growth plate cartilage. J Endocrinol 194: 31-40, 2007.
44. Sadler TW (ed): Limbs. In: Langman's Medical Embryology. Lippincott Williams and Wilkins, Philadephia, PA, 12th edition, pp151-152.

45. Sifakis S, Basel D, Ianakiev P, Kilpatrick M and Tsipouras P: Distal limb malformations: underlying mechanisms and clinical associations. Clin Genet 60: 165-172, 2001.

46. Kaplowitz PB, D'Ercole AJ and Underwood LE: Stimulation of embryonic mouse limb bud mesenchymal cell growth by peptide growth factors. J Cell Physiol 112: 353-359, 1982.

47. Bhaumick B and Bala RM: Receptors for insulin-like growth factors I and II in developing embryonic mouse limb bud. Bioch Bioph Acta 927: 117-128, 1987.

48. Geduspan JS and Solursh M: Effects of the mesonephros and insulin-like growth factor I on chondrogenesis of limb explants. Dev Biol 156: 500-508, 1993.

49. Streck RD, Wood TL, Hsu MS and Pintar JE: Insulin-like growth factor I and II and insulin-like growth factor binding protein 2 RNAs are expressed in adjacent tissues within rat embryonic and fetal limbs. Dev Biol 151: 586-596, 1992.

50. Ralphs JR, Wylie L and Hill DJ: Distribution of insulin-like growth factor peptides in the developing chick embryo. Development 109: $51-58,1990$

51. Geduspan JS, Padanilam BJ and Solursh M: Coordinate expression of IGF-I and its receptor during limb outgrowth. Dev Dyn 195: 67-73, 1992

52. Mc Queeney $\mathrm{K}$ and Dealy $\mathrm{CN}$ : Roles of insulin-like growth factor-I (IGF-I) and IGF-I binding protein-2 (IGFBP2) and -5 (IGFBP5) in developing chick limbs. Growth Horm IGF Res 11: 346-363, 2001.

53. van Kleffens M, Groffen C, Rosato RR, et al: mRNA expression patterns of the IGF system during mouse limb bud development determined by whole mount in situ hybridization. Mol Cell Endocrinol 138: 151-161, 1998

54. Wang E, Wang J, Chin E, Zhou J and Bondy CA: Cellular patterns of insulin-like growth factor system gene expression in murine chondrogenesis and osteogenesis. Endocrinology 136: 2741-2751, 1995.

55. Allan GJ, Flint DJ, Darling SM, Geh J and Patel K: Altered expression of insulin-like growth factor 1 and insulin-like growth factor binding proteins 2 and 5 in the mouse mutant Hypodactyly (Hd) correlates with sites of apoptotic activity. Anat Embryol (Berl) 202: 1-11, 2000.

56. Lok F, Owens JA, Mundy L, Robinson JS and Owens PC: Insulin-like growth factor I promotes growth selectively in fetal sheep in late gestation. Am J Physiol 270: R1148-R1155, 1996.

57. Mathews LS, Hammer RE, Behringer RR, et al: Growth enhancement of transgenic mice expressing human insulin-like growth factor I. Endocrinology 123: 2827-2833, 1988.

58. Dealy CN and Kosher RA: Studies on insulin-like growth factor-I and insulin in chick limb morphogenesis. Dev Dyn 202: 67-79, 1995.

59. Mesiano S, Young IR, Baxter RC, Hintz RL, Browne CA and Thorburn GD: Effect of hypophysectomy with and without thyroxine replacement on growth and circulating concentrations of insulin-like growth factors I and II in the fetal lamb. Endocrinology 120: $1821-1830,1987$.

60. Bikle D, Majumdar S, Laib A, et al: The skeletal structure of insulin-like growth factor I-deficient mice. J Bone Miner Res 16: 2320-2329, 2001.

61. Burghardt AJ, Wang Y, Elalieh H, et al: Evaluation of fetal bone structure and mineralization in IGF-I deficient mice using synchrotron radiation microtomography and Fourier transform infrared spectroscopy. Bone 40: 160-168, 2007.

62. Woods KA, Camacho-Hübner C, Barter D, Clark AJL and Savage MO: Insulin-like growth factor I gene deletion causing intrauterine growth retardation an severe short stature. Acta Paediatr Suppl 423: 39-45, 1997.

63. Netchine I , Azzi S, Housang M, et al: Partial primary deficiency of insulin-like growth factor (IGF)-I activity associated with IGF1 mutation demonstrates its critical role in growth and brain development. J Clin Endocrinol Metab 94: 3913-3921, 2009.

64. Bonapace G, Concolino D, Formicola S and Strisciuglio P: A novel mutation in a patient with insulin-like growth factor 1 (IGF1) deficiency. J Med Genet 40: 913-917, 2003.

65. Coutinho DC, Coletta RR, Costa EM, et al: Polymorphisms identified in the upstream core polyadenylation signal of IGF1 gene exon 6 do not cause pre- and postnatal growth impairment. J Clin Endocrinol Metab 92: 4889-4892, 2007.

66. van Duyvenvoorde HA, van Setten PA, Walenkamp MJE, et al: Short stature associated with a novel heterozygous mutation in the insulin-like growth factor 1 gene. J Clin Endocrinol Metab 95: E363-E367, 2010 
67. van Duyvenvoorde HA, van Doorn J, Koenig J, et al: The severe short stature in two siblings with a heterozygous IGF1 mutation is not caused by a dominant negative effect of the putative truncated protein. Growth Hormone IGF Res 21: 44-50, 2011.

68. Abuzzahab MJ, Schneider A, Goddard A, et al: IGF-I receptor mutations resulting in intrauterine and postnatal growth retardation. N Engl J Med 349: 2211-2222, 2003.

69. Kawashima Y, Kanzaki S, Yang F, et al: Mutation at cleavage site of insulin-like growth factor receptor in a short-stature child born with intrauterine growth retardation. J Clin Endocrinol Metab 90: 4679-4687, 2005.

70. Raile K, Klammt J, Schneider A, et al: Clinical and functional characteristics of the human Arg59Ter insulin-like growth factor I receptor (IGF1R) mutation: implication for a gene dosage effect of the human IGF1R. J Clin Endocrinol Metab 91: 2264-2271, 2006.

71. Walenkamp MJ, van der Kamp HJ, Pereira AM, et al: A variable degree of intrauterine and postnatal growth retardation in a family with a missense mutation in the insulin-like growth factor I receptor. J Clin Endocrinol Metab 91: 3062-3070, 2006

72. Inagaki K, Tiulpakov A, Rubtsov P, et al: A familial insulin-like growth factor I receptor mutant leads to short stature: clinical and biochemical characterization. J Clin Endocrinol Metab 92: 1542-1548, 2007.

73. Kruis T, Klammt J, Galli-Tsinopoulou A, et al: Heterozygous mutation within a kinase-conserved motif of the insulin-like growth factor I receptor causes intrauterine and postnatal growth retardation. J Clin Endocrinol Metab 95: 1137-1142, 2010.
74. Wallborn T, Wüller S, Klammt J, et al: A heterozygous mutation of the insulin-like growth factor-I receptor causes retention of the nascent protein in the endoplasmic reticulum and results in intrauterine and postnatal growth retardation. J Clin Endocrinol Metab 95: 2316-2324, 2010

75. Choi JH, Kang M, Kim GH, et al: Clinical and functional characteristics of a novel heterozygous mutation of the IGF1R gene and IGF1R haploinsufficiency due to terminal 15q26.2->qter deletion in patients with intrauterine growth retardation and postnatal catch-up growth failure. J Clin Endocrinol Metab 96: E130-E134, 2011.

76. Roback EW, Barakat AJ, Dev VG, Mbikay M, Chrétien M and Butler MG: An infant with deletion of the distal long arm of chromosome 15 (q26.1 - qter) and loss of insulin-like growth factor I receptor gene. Am J Med Genet 38: 74-79, 1991.

77. Walemkamp MJ, de Muinck Keizer-Schrama SM, de Mos M, et al: Successful long-term growth hormone therapy in a girl with haploinsufficiency in the insulin-like growth factor-I receptor due to a terminal 15q26.2->qter deletion detected by multiplex ligation probe amplification. J Clin Endocrinol Metab 93: 2421-2425, 2008.

78. Fang P, Schwartz ID, Johnson BD, et al: Familial short stature caused by haploinsufficiency of the insulin-like growth factor I receptor due to nonsense-mediated messenger ribonucleic acid decay. J Clin Endocrinol Metab 94: 1740-1747, 2009.

79. Ester WA, van Duyvenvoorde HA, de Wit CC, et al: Two short children born small for gestational age with insulin-like growth factor 1 receptor haploinsufficiency illustrate the heterogeneity of its phenotype. J Clin Endocrinol Metab 94: 4717-4727, 2009. 